\title{
电力大客户业扩工程项目管理分析
}

房媛

国网山东省电力公司栖霞市供电公司

DOI:10.32629/hwr.v2i11.1675

[摘 要] 电力大客户业扩工程主要表现为电力大客户的临时用电和变更用电。电力大客户业扩工程项目管理直接关系到供 电公司的日常管理质量和效率。因此相关部门要从供电公司的整体利益出发,优化电力大客户业扩工程流程, 为电力大客户提 供优质服务, 提高供电公司的市场竞争力。基于此, 本文概述了电力大客户, 阐述了电力大客户业扩工程项目管理的重要性及其 主要内容,对电力大客户业扩工程项目管理的现状及其策略进行了探讨分析。

[关键词] 电力大客户；业扩工程项目管理；重要性；内容；现状；策略

电力大客户对于供电公司运营质量和效益非常重要, 因 此供电公司负责人要注重对其业扩工程进行管理, 为其提供 更加优质的服务。并且随着电力市场竞争的日渐激烈, 使得 电力大客户业扩工程项目管理的日显重要。

\section{1 电力大客户的概述}

电力大客户主要分为以下几种: 用电容量和电力使用意 义较大的工业用户; 单位性质较特殊的电力用户; 电力使用 潜在大客户, 其中包括和供电公司存在竞争的能源, 例如正 使用燃煤或燃油锅炉的客户。电力大客户的特征主要表现 为: 第一、电力大客户用电过程中通常使用的电压等级较高、 电力设备的容量较大, 电力线路设置较复杂, 如果在使用的 过程中直接和系统进行连接, 会给系统的正常使用造成影 响。第二、电力大客户主要是代表大中型的用电企业, 其中 电力的供应可靠性对于企业的运转有着十分重要的影响。第 三、电力大客户的用电量较大, 产生的费用也较高。供电公 司对其进行电费收取的效果对企业自身的经济效益影响较 大。第四、电力大客户中普遍具有较强的法律意识, 对于电 力政策的把握程度较高, 供电公司在对其进行电力营销策略 的使用将使企业自身的销售业绩产生着直接的影响。在地方 经济的发展过程中, 电力大客户是其中重要的因素。

\section{2 电力大客户业扩工程项目管理的重要性及其主要内容}

2.1 电力大客户业扩工程项目管理的重要性

供电部门用电管理的一项非常重要的工作就是业扩工 程, 它是供电企业实施扩大再生产、满足国家有关部门和人 民生活用电需求的一项关键工作。电力大客户业扩工程的实 施情况, 对供电企业的质量与形象起着重要作用。随着电力 大客户业扩报装数量和规模的不断扩大, 业扩工程建设数量 也逐渐增加, 供电公司服务工程项目的工作难度也随之扩 大。目前供电公司对业扩工程进行管理的过程中存在着职能 交叉、分工不明的现象使得在前期报装服务与后期项目管理 的过程中不仅投入的人力、物力成本较高、产生的资源浪费 现象也较重, 影响各方工作效率, 从而大大影响了供电公司 的在市场中的竞争力。在电力大客户业扩工程中需要制定相 应的服务规划, 通过对施工过程进行有力控制从而提高各方
工作效率、改进工作质量, 在有限的资源和成本基础上增加 项目的效益, 在各个项目活动中做到资源的合理分配, 使得 有效的资源能够发挥最大的作用, 根据工程质量要求定期完 成业扩工程, 增强客户的满意度以及提升供电效益。

2.2 电力大客户业扩工程项目管理的主要内容

电力大客户业扩服务范围是对用电客户的用电申请进 行受理到正式对客户进行供电这一周期。其属于供电公司的 售前服务范畴。业扩工程涵盖的范围很广, 包括工程设计、 审核、设备购买、施工、检查和竣工验收等。其管理内容主 要有:（1)监督与协调客户业扩工程的进度; (2)负责施工现 场的勘查与方案的审核; (3) 负责审查大客户内部电气工程 图纸与监督有关工作人员对内部电气工程施工的检查; (4) 负责评审大客户供用电合同, 并对某些不确定的内容进行协 商与确定; (5) 对大客户用电中的问题实施协调, 有效保证电 力大客户的切身利益。

\section{3 电力大客户业扩工程项目管理的现状及其策略分析}

3.1 电力大客户业扩工程项目管理的现状分析

主要表现为:（1）电力大客户的差异性决定了其业扩工 程项目存在偏差, 使得业扩工程存在诸多问题。部分电力大 客户强调供电时效性, 离不开供电公司各部门的相互合作。 但是在协作过程中, 责任不明确, 实施程序比较繁杂, 严重影 响了客户的利益, 以及供电公司的整体效益和信誉度。同时, 也无法保障在规定时间内完成业扩工程项目。(2) 当前部分 供电公司已经应用客户经理责任制和 VIP 客户管理模式为 电力大客户进行业扩工程服务。但是在实际操作过程中, 客 户经理缺乏市场认知度, 不能从根本上满足电力大客户的需 求, 导致电力主动营销过程中诸多问题的存在。客户经理没 有结合大客户的特征和实际诉求对其进行服务, 服务方法和 模式过于简单, 导致电力大客户业扩工程项目管理过程中的 粗放性, 严重制约了业扩工程项目质量。(3) 电力大客户业扩 工程对管理流程要求比较高。电力大客户业扩工程项目管理 在具体操作过程中普遍存在沟通方面的问题。例如, 电力大 客户业扩工程项目流转通过纸质联系单的方式实现, 传送过 程衔接性不够; 服务过程不够透明; 当前并没有形成针对性 
的大客户业扩信息管理系统, 电力大客户业扩工程项目管理 过程中以营销系统和复核管理系统等为主, 无法实现供电公 司资源的整合和信息的共享。

3.2 加强电力大客户业扩工程项目管理的策略

具体体现在：（1）转变服务理念及服务方式。将原有的浅 层服务方式转变为深层次的服务, 分析客户的深度需求, 充分 利用现代化的营销和服务理念, 多举措提升业扩工程项目的管 理水平。在进行供电营销的过程中鼓励全员参与, 生产围绕营 销转、营销围绕客户转。在以往的供电公司的发展过程中由于 诸多原因, 使得电力营销理念较为单一, 只将管理功能作为重 点, 忽略了供电公司的服务功能。在供电公司的营销过程中, 不仅负责电力的销售, 同时还包括相关的服务项目。只保证供 电管理, 使得市场的开发效果较差, 影响到了供电公司在市场 中的竞争能力, 在企业的发展过程中, 要建立起相应的激励机 制, 从根本上转变员工的工作思想, 使得员工能够从根本上转 变服务态度, 提高服务质量, 充分发掘具有潜力的客户和留住 大客户。(2) 强化供电公司业扩工程的现代化管理, 建立起专门 针对业扩工程的进度管理跟踪系统, 以此加强工程管理中涉及 到供电公司各部门间的服协同能力。业扩项目经理对大客户的 相工程关信息进行准确掌握, 在业扩管理过程中使用及时的跟 踪系统进行部门间的交流, 在之前一个部门的工作完成后通过 系统传送到与之相关的下一个部门中, 此时, 下一个部门中的 负责人根据规定流程要求执行相应的操作。在业扩工程项目中, 业扩项目经理是其中主要的负责人, 采用这种形式能够对工程 的各项进度进行实时地监控, 如果其中的任何一个部门没有按 时完成任务, 系统就会进行自动提醒。(3) 互联网技术优化业扩 工程项目管理。利用云计算、大数据等新型信息技术创新服务 理念和服务方式, 使电力大客户业扩工程项目管理更加精细, 摒弃传统粗放的管理模式, 积极开发出精细化的项目管理服务 模式, 提升项目管理效率, 改善服务质量。通过优化和改善业扩 工程项目管理, 吸引并留住原有大客户, 同时进一步开拓和挖 掘潜在客户。利用 “互联网+” 进行信息融合创新, 不断发展新
型业态, 营造出新的业务增长点, 为大客户业扩工程项目提供 新环境, 为电力业智能化提供支撑, 并利用新型信息技术为企 业与大客户之间建立良好的互动沟通机制, 从而增加电力企业 的发展动力。(4)强化从业人员培训, 以提升其综合素质。加大 对业扩工作人员特别是业扩项目经理的技能培训, 加强其服务 技能的学习, 完善其专业知识架构。在供电公司中定期开展有 针对性业务交流会和专业培训班, 利用供电公司内部人才优势, 统一培训资源, 多角度拓宽业扩人员服务能力, 重点侧重于电 力设计、运维检修、服务规范专业。通过培训, 努力提高业扩 工作人员综合业务能力, 培养出具有生产、营销、建造、规划 设计能力的复合型人才。同时业扩项目经理也需树立起项目全 面管理的意识,切实对客户业扩项目负责, 主动为客户提供优 质的服务, 利用掌握到的市场信息, 有效结合专业技能, 促进业 扩项目工作的顺利推进。

\section{4 结束语}

综上所述, 电力大客户对于促进供电公司发展非常关键, 因此在激烈的市场竞争环境中需要争取更多的电力大客户。 并且加强对电力大客户进行业扩工程管理, 是供电公司实现 优质服务的基础和前提, 直接关系到供电公司的市场形象。 所以供电公司负责人要将电力大客户作为日常服务的核心, 加强电力大客户业扩工程项目管理。

[参考文献]

[1]陈雅晶.剖析加强电力大客户业扩工程项目管理的 重要性[J].企业技术开发,2016,(12):46.

[2]黄丽华.电力大客户业扩工程项目管理研究[J].科技 创新与应用,2015,(32):37.

[3]戴向东.电力大客户业扩工程项目管理分析[J].科技 资讯,2017,(10):35+41。

[4]卓建平.电力大客户业扩工程项目管理服务探讨 [J]. 中国房地产业,2017,(12):54-55.

[5]杨明明.电力大客户业扩工程中存在的问题与对策研 究[J].中国科技博览,2017,(48):31-32. 